\title{
EXAMINING THE DIGITAL ENTREPRENEURSHIP EDUCATION EFFECTIVENESS ON SOFT SKILLS AMONG UNDERGRADUATES
}

\author{
${ }^{1}$ NUR THARA ATIKAH ZAINAL \\ ${ }^{2}$ KELVIN YONG

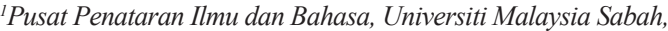 \\ Jalan UMS, 88400, Kota Kinabalu, Sabah. \\ ${ }^{2}$ Fakulti Perniagaan, Ekonomi dan Perakaunan, Universiti Malaysia Sabah, \\ Jalan UMS, 88400, Kota Kinabalu, Sabah. \\ 'tharazainal@ums.edu.my; ${ }^{2} k$ kelvinyong83@gmail.com \\ Dihantar: 29 Nov 2019/Diterima: 20 Mac 2020
}

\begin{abstract}
The Fundamentals of Entrepreneurship Acculturation Course is one of the curriculum of higher learning institutions in Malaysia to enhance the soft skills of undergraduates required for the job market. The emergence of digital technologies has led to the integration of the digital entrepreneurship module into the existing entrepreneurship course. Nonetheless, there is a dearth of recent literature relevant to the effectiveness of digital entrepreneurship education and its impact on students' soft skills. The main purpose of this study is therefore to investigate the impact of digital entrepreneurship education on soft skills of undergraduates at public higher learning institution in East Malaysia. The study collected secondary data which included course feedback forms of 2,454 second year undergraduate students from two different academic years. Overall, the findings show that the digital entrepreneurship education enhanced the students' soft skills. However, leadership skills were the lowest that students gained in both academic years. The findings provide practical implications for higher learning institutions on the importance of digital entrepreneurship education to the soft skills of undergraduates, and on the need to improve teaching and learning methods to equally enhance the soft skills.
\end{abstract}

Keywords: Soft skills, entrepreneurship education, digital entrepreneurship. 


\section{INTRODUCTION}

Several universities in Malaysia reported that graduates do not have a job after one year of graduation (Fabeil, 2019). A recent study by Hanapi and Nordin (2014) found that Malaysian graduates were not employed by employers due to lack of soft skills. Good academic achievements can therefore no longer ensure that graduates are employed (Fabeil, 2019; Rahim, Abidin \& Rosly, 2016). In addressing the importance of equipping graduates with soft skills, the Malaysia's Ministry of Higher Education (MOHE) has listed seven main soft skills to be integrated into the design of public university curricula. These soft skills include teamwork skills, communication skills, critical thinking and problem-solving skills, ethics and professional moral skills, leadership skills, entrepreneurship skills, and lifelong learning and information management skills (Shakir, 2009). One of the curriculums to enhance the undergraduates' soft skills is the Fundamentals of Entrepreneurship Acculturation Course. It is an entrepreneurship course, introduced in 2007, for all science and non-science students in all higher learning institutions in Malaysia.

Starting in 2016, the digital entrepreneurship module was integrated into the existing entrepreneurship course at higher learning institutions in Malaysia. This integration was due to the proliferation of digital technologies such as social media and websites, which have changed the job market and business environment. Digital entrepreneurship was considered to be one of the emerging topics in Malaysian education in line with the Industrial Revolution 4.0. However, how effective has this digital entrepreneurship education since its integration? A recent study by Rahim et al. (2016) found that entrepreneurship education effectiveness positively influences soft skills such as communication skills, problem-solving skills, leadership skills and human skills. There have been numbers of studies on the effectiveness of entrepreneurship education in Malaysia (e.g. Mohamed, Rezai, Shamsudin \& Mahmud, 2012; Ahmad, Ismail \& Buchanan, 2014; Rahim et al., 2016)a total of 506 students completed the General Enterprising Tendency (version 2, but there is a dearth of recent research relevant to this concept. Specifically, there is a lack of literature relevant to the effectiveness of digital entrepreneurship education and its impact on students' soft skills (e.g. Rahim et al., 2016). The 
main purpose of this study is therefore to investigate the impact of digital entrepreneurship education on soft skills of undergraduates at a public higher learning institution in East Malaysia. In particular, this paper explores the integration of digital entrepreneurship education before and after that. This study is hoped to be of benefit to educators and training institutions to provide guidance on the significance of the digital entrepreneurship education in Malaysia in enhancing student soft skills.

Firstly, the paper presents the methodology that was used in the research. This paper then explores the literature relevant to digital entrepreneurship education and its relationship to soft skills in the following section, followed by the results of secondary data analysis. Finally, this paper concludes the implications of the study with recommendations for future research.

\section{METHODOLOGY}

This study employed a quantitative approach at a public university in East Malaysia that integrated the digital entrepreneurship module in early 2018. The study collected secondary data on the response of undergraduates to the feedback form of the Fundamentals of Entrepreneurial Acculturation course assessment. These course feedback forms were completed by the undergraduates at the end of each semester through an online student information system. The forms were in dual-language context using Bahasa Malaysia and English. It includes questions about the preparation, the delivery of lectures, assessment, learning outcomes, the facility of the course and soft skills enhanced from course. Specifically, in the soft skills category, it included items related to the course's enhancement of communication skills, critical thinking and problem-solving skills, teamwork skills, leadership skills, knowledge in moral and professional ethics, lifelong learning and information management ability and entrepreneurship skills. These are the seven soft skills focused by the higher learning institutions (Shakir, 2009). In this online form, students are required to rate a scale of the course feedback form from 1 to 5 . Thus, these feedback forms allowed the study to gain insight into the undergraduate's perspectives on the effectiveness of digital entrepreneurship education in enhancing their soft skills. 
The study collected secondary data on the Fundamentals of Entrepreneurial Acculturation course feedback forms of 2,454 undergraduate students. Specifically, the study retrieved responses from undergraduates who attended the course in the academic year 2016/2017 $(\mathrm{n}=1,218)$, and $2018 / 2019(n=1,236)$. All students were in their second year of study. The results of the feedback forms were generated from the student information system, without the use of any statistical tools such as Statistical Package for Social Sciences (SPSS). Hence, the results of the responses showed only the total average of the total mean values for each category. The study used a consecutive sampling method. It is a strict form of convenience sampling, in which all available subjects are chosen, ensuring that the entire accessible population were studied (Lunsford \& Lunsford, 1995). In terms of data analysis, a descriptive analysis of the mean was used to analyse the data.

\section{LITERATURE REVIEW}

\section{Digital Entrepreneurship Education}

Several authors argue that entrepreneurship is a given talent (Morris, Kuratko \& Schindehutte, 2001), while some argue that knowledge and skills in entrepreneurship can be gained and trained through entrepreneurship education (Drucker, 1985; Gorman, Hanlon \& King, 1997). Cheng, Chan and Mahmood (2009) point out that entrepreneurship education is about "learning", and it is a:

"Formalised programme to equip students with the needed skills and knowledge to recognise business opportunities, search customers' insights, network and understand the needs of the market, create ideas, develop a business plan, run a business and evaluate environmental, institutional and political issues." (Cheng et al., 2009: 558)

Othman and Nasrudin (2016) supported this argument and posit that entrepreneurship education focuses on providing the knowledge and skills needed through awareness and training for the development and growth of an entrepreneur. 
The emergence of digital technologies has transformed the job market and business environment in general. It is therefore important to identify the emerging opportunities it brings, particularly in the field of entrepreneurship education. Digital entrepreneurship can be defined as "a subcategory of entrepreneurship in which some or all of what would be physical in a traditional organization has been digitized" (Hull, Hung, Hair et al., 2007: 293). Hence, it leverages the "digital technologies for creating and doing business in the digital era" (Rippa \& Secundo, 2019: 901). This suggests that digital entrepreneurship education is a subcategory of entrepreneurship education that leverages digital technologies and provides entrepreneurial knowledge and skills. Although there is interest in digital entrepreneurship, there is still a lack of research on this concept (Yaghoubi Farani, Karimi $\&$ Motaghed, 2017). Specifically research on the intersection of digital entrepreneurship and education, few studies have addressed this topic. Moreover, there is very little literature on digital entrepreneurship education.

\section{Soft Skills and Digital Entrepreneurship Education}

A study by Murah and Abdullah (2012) shows that teaching and learning that focuses on entrepreneurship is capable of encouraging knowledge and skills among tertiary students and has the potential to be life-long entrepreneurs. This suggests that the entrepreneurial knowledge and skills derived from this education can be used throughout their lifetime (Raposo \& do Paço, 2011). This study focuses on the skills acquired through entrepreneurship education.

Skills could be categorized as skills that are hard and soft. The hard skills are related to technical and practical skills that can be observed, quantified and measured (Shakir, 2009). On the other hand, soft skills are known as the behavioural skills needed in organisations to apply hard skills and knowledge (Rainsbury, Hodges, Burchell \& Lay, 2002). In addition, researchers argue that soft skills are the skills and talents of an individual. Higher learning institutions are important in providing education in entrepreneurship that can equip students with the needed soft skills (Humsona \& Yuliani, 2018; Hytti \& O'Gorman, 2004; Toding $\&$ Venesaar, 2018). There are seven soft skills focused by the MOHE to equip the undergraduates. These seven soft skills include teamwork skills, 
communication skills, critical thinking and problem-solving skills, ethics and professional moral skills, leadership skills, entrepreneurship skills and lifelong learning and information management skills (Shakir, 2009). Therefore, these seven soft skills are important for higher learning graduates to meet the needs of the working environment. However, Shakir (2009) explained that soft skills are difficult to develop among the undergraduate students as they "involves less measurable elements and varies highly with each individual according to their character and background” (p. 310).

Different studies have examined the development of soft skills in higher learning institutions (e.g. Adnan, Daud, Alias et al., 2012; Rahim et al., 2016; Salleh, Sulaiman, Mohamad et al., 2017; Mohamad, Muhammad, Mohd Hussin et al., 2017; Brown, 2018). From the organisations perspective, Adnan et al. (2012) found that employers highly value ethics and professional skills. This is followed by critical thinking and problemsolving skills, teamwork skills, leadership skills and communication skills, information management and lifelong learning and entrepreneurship skills. In another study by Brown (2018), the author found that communication skills, critical thinking and problem-solving skills are valuable skills and are desirable in organizations. From the students' perspective, Mohamad et al (2017) found that the majority of accounting students at a Malaysian higher learning institution stated that critical thinking and problemsolving skills were achieved after completing the accounting course. This is followed by team building skills, lifelong learning and information management skills, communication skills, ethics, moral and professional skills, leadership skills and entrepreneurship skills. In a study by Salleh et al. (2017) at the Malaysian Technical University Network, they found that collaboration skills were ranked highest, followed by communication skills and entrepreneurship skills. In the entrepreneurship education context, Rahim et al. (2016) found that its effectiveness has a positive impact on the students' soft skills such as communication skills, problem-solving skills, leadership skills and human skills. Therefore, the literature suggests that education may influence students' soft skills. Additionally, the literature indicates that problem-solving skills are one of the highest soft skill to be sought by the employers or skills to be attained after completion a specific course. On the other hand, the leadership skills are one of the least 
attained skills after completion of a course. However, how effective is the digital entrepreneurship education in developing students' soft skills in higher learning institutions? There are still several aspects of digital entrepreneurship education about which relatively little is known.

\section{RESULTS}

In this section, Table 1 shows the mean value of the seven soft skills ranked from high to low. Based on Table 1, the sum mean for the 2016/2017 academic year was 4.42. Specifically, the mean value for the students' soft skills in the $2016 / 2017$ academic year ranged from 4.39 to 4.44 . Entrepreneurship skills received the highest mean value of 4.44 , followed by communication skills, teamwork skills and lifelong learning and information management skills, each of which received a mean value of 4.42 . Critical thinking and problem-solving skills and knowledge in moral and professional ethics each received a mean value of 4.41. Finally, leadership skills received the lowest mean value of 4.39. On the other hand, the sum mean for the 2018/2019 academic year was 4.69. There were six soft skills with a similar mean value of 4.69. These soft skills include entrepreneurship skills, communication skills, teamwork skills, lifelong learning and information management skills, critical thinking and problem-solving skills and knowledge in moral and professional ethics. Leadership skills had a slightly lower mean value (4.68) than the rest of the six soft skills. However, all of these seven skills have almost the same mean value in the 2018/2019 academic year. 
Table 1 Mean value of seven soft skills, ranked high to low

\begin{tabular}{|l|c|c|}
\hline \multicolumn{1}{|c|}{ Soft Skills } & $\begin{array}{c}2016 / 2017 \\
\text { (average) }\end{array}$ & $\begin{array}{c}2018 / 2019 \\
\text { (average) }\end{array}$ \\
\hline Enhancement of entrepreneurship skills & 4.44 & 4.69 \\
Enhancement of communication skills & 4.42 & 4.69 \\
Enhancement of teamwork skills & 4.42 & 4.69 \\
Enhancement of lifelong learning and information & 4.42 & 4.69 \\
management ability & 4.41 & 4.69 \\
Enhancement of critical thinking and problem-solving & & \\
skills & 4.41 & 4.69 \\
Enhancement of knowledge in moral, and professional \\
ethics
\end{tabular}

Note: Retrieved from course assessment feedback forms from a university in East Malaysia.

Overall, from 2016/2017 academic year to 2018/2019 academic year, the sum mean value increased from 4.42 to 4.69 . Hence, the finding suggests that the integration of digital entrepreneurship into the existing entrepreneurship course at the beginning of 2018 further enhanced the seven soft skills of the undergraduates. This could be explained by the fact that the university in East Malaysia has integrated digital marketing practice into the existing entrepreneurship education, which makes the education more relevant to the digital age. Therefore, the practice may have improved the student engagement in the learning process. As a result, their improved engagement in the entrepreneurial learning process may have further enhanced their soft skills.

Notably, the finding shows that all the seven soft skills in both academic years have a very high mean value. This could be explained as the Fundamentals of Entrepreneurial Acculturation Course has delivered a course aimed at enhancing all seven soft skills. In addition, it is important to note that between the academic year 2016/2017 and 2018/2019, the seven skills were ranked similarly. In Table 1, the soft skills are ranked from high to low. The entrepreneurship skills are ranked among the highest, 
followed by communication skills, teamwork skills, lifelong learning and information management ability, critical thinking and problem-solving skills and knowledge in moral and professional ethics. However, a significant result shows that the leadership skills received the lowest mean value in both academic years.

The findings of the current study do not support the previous findings by Rahim et al. (2016) and Mohamad et al. (2017) which found that the entrepreneurship skills were the least attained soft skills among undergraduates. This could be because the digital entrepreneurship course focuses on developing entrepreneurial skills that could be applied in the real world. Nonetheless, the findings of the current study support the earlier findings by Rahim et al. (2016) and Mohamad et al. (2017) that leadership skills are one of the least attained soft skills. This result may indicate that entrepreneurship education or digital entrepreneurship education may not have influenced the leadership skills in the same way as other skills. Furthermore, it could be because the course was mostly involving students in group projects. Not all students can lead their groups. Overall, the findings show that the digital entrepreneurship education is important to enhance the seven soft skills of the undergraduates (Rahim et al., 2016).

\section{CONCLUSION}

Digital entrepreneurship education is the integration of digital entrepreneurship and entrepreneurship education, one of the approaches to equip students of the higher learning institutions with the soft skills needed to ensure that they are employable and competent in line with the Industrial Revolution 4.0. However, there is a lack of research on the effectiveness of digital entrepreneurship education and its impact on students' soft skills (e.g. Rahim et al., 2016). The primary objective of this paper is therefore to examine the effect of digital entrepreneurship education on students' soft skills at a public higher learning institution in East Malaysia. Based on the findings, not only the integration of digital entrepreneurship education had a positive impact on the seven soft skills, but it also significantly enhanced these seven soft skills since their integration. Nonetheless, it is important 
to note that leadership skills were ranked the lowest among other soft skills in both 2016/2017 and 2018/2019 academic years.

The research contributes to the digital entrepreneurship education literature by investigating the influence of the concept on the soft skills of undergraduates. Since the emergence of digital entrepreneurship education, little is known about this concept and its effectiveness in developing the soft skills of undergraduates. In addition, this research contributes to the practical implications. First, higher learning institutions should consider the importance and effectiveness of digital entrepreneurship education, which could significantly enhance the soft skills needed by undergraduates to be employed. Second, as both traditional and digital entrepreneurship education have the least impact on the leadership skills of the undergraduates, there is a need for higher learning institutions to improve their teaching and learning methods. The institutions may need to carry out activities or assessments that give all students the opportunity to lead or take accountability. Nonetheless, each higher learning institution must ensure that the teaching and learning methods are able to enhance every soft skill element of the undergraduates, depending on the importance of the skills needed on the job market. Thus, this may enhance competitiveness of the undergraduates.

There are few limitations to this research that need to be addressed. This research explored the concept of digital entrepreneurship education and its relationship with undergraduate soft skills using a quantitative approach and secondary data. The research was only able to retrieve mean values of the seven soft skills from the course assessment feedback forms. These forms did not allow the researchers to gain further insight on the course influence on the soft skills of the students. It is therefore suggested that future researchers should retrieve primary data, using a qualitative approach in order to gain an in-depth understanding of digital entrepreneurship education and its impact on the students' soft skills. The approach could include multiple methods such as focus groups, netnography and document analysis of students' written reports (e.g. business plan and business portfolio written report) and presentation slides (pre-business and post business pitching. The qualitative research will enable future researches to gain a better understanding of the effectiveness of digital entrepreneurship education. 


\section{REFERENCES}

Adnan, Y. M., Daud, M. N., Alias, A. \& Razali, M. N. (2012). Importance of soft skills for graduates in the real estate programmes in Malaysia. Journal of Surveying, Construction \& Property, 3 (2), 1-13. https://doi. org/10.1167/2.7.582

Ahmad, S. Z., Ismail, M. Z. \& Buchanan, F. R. (2014). Examining the entrepreneurship curriculum in Malaysian polytechnics. International Journal of Management Education, 12, 397-406. https://doi.org/10.1016/j. ijme.2014.06.004

Brown, L. S. (2018). Soft skill development in the higher education curriculum: A case study. The IUP Journl of Soft Skills, 12 (4), 7-29.

Cheng, M. Y., Chan, W. S. \& Mahmood, A. (2009). The effectiveness of entrepreneurship education in Malaysia. Education and Training, 51 (7), 555-566. https://doi.org/10.1108/00400910910992754

Drucker, P. F. (1985). Innovation and entrepreneurship: Practice and principles. New York, NY: Harper \& Row.

Fabeil, N. F. (2019). Entrepreneurship education and entrepreneurial behaviour among undergraduate students in Sabah, Malaysia. Journal of Economics and Business, 2 (4), 1064-1072. https://doi.org/10.31014/aior.1992.02.04.151

Gorman, G., Hanlon, D. \& King, W. (1997). Some research perspectives on entrepreneurship education, enterprise education and education for small business management: A ten-year literature review. International Small Business Journal, 15 (3), 56-77. https://doi.org/10.1177/0266242697153004

Hanapi, Z. \& Nordin, M. S. (2014). Unemployment among Malaysia graduates: Graduates'attributes, lecturers' competency and quality of education. Procedia Social and Behavioral Sciences, 112, 1056-1063. https://doi. org/10.1016/j.sbspro.2014.01.1269

Hull, C. E., Hung, Y. T. C., Hair, N., Perotti, V. \& DeMartino, R. (2007). Taking advantage of digital opportunities: A typology of digital entrepreneurship. International Journal of Networking and Virtual Organisations, 4 (3), 290-303. https://doi.org/10.1504/IJNVO.2007.015166

Humsona, R. \& Yuliani, S. (2018). How does entrepreneurship education develop soft skills? IOP Conference Series: Materials Science and Engineering. https://doi.org/10.1088/1757-899X/306/1/012107

Hytti, U. \& O'Gorman, C. (2004). What is enterprise education? An analysis of the objectives and methods of enterprise education programmes in four European countries. Education and Training Training, 46 (1), 11-23. https:// doi.org/10.1108/00400910410518188 
Lunsford, T. R. \& Lunsford, B. R. (1995). The research Sample, Part 1: Sampling. Journal of Prosthetics and Orthotics, 7(3).

Mohamad, S. I. S., Muhammad, F., Mohd Hussin, M. Y. \& Habidin, N. F. (2017). College students' perceptions of the embedded soft skills elements program in accounting courses. International Journal of Academic Research in Business and Social Sciences, 7 (2), 778-784. https://doi.org/10.6007/ IJARBSS/v7-i2/2686

Mohamed, Z., Rezai, G., Shamsudin, M. N. \& Mahmud, M. M. az. (2012). Enhancing young graduates' intention towards entrepreneurship development in Malaysia. Education and Training, 54 (7), 605-618. https:// doi.org/10.1108/00400911211265648

Morris, M. H., Kuratko, D. F. \& Schindehutte, M. (2001). Towards integration: Understanding entrepreneurship through frameworks. The International Journal of Entrepreneurship and Innovation, 2 (1), 35-49. https://doi. org $/ 10.5367 / 000000001101298765$

Murah, M. Z. \& Abdullah, Z. (2012). An experience in transforming teaching and learning practices in technology entrepreneurship course. Procedia Social and Behavioral Sciences, 59, 164-169. https://doi.org/10.1016/j. sbspro.2012.09.261

Othman, N. \& Nasrudin, N. (2016). Entrepreneurship education programs in Malaysian polytechnics. Education and Training, 58 (7-8), 882-898. https:// doi.org/10.1108/ET-11-2014-0136

Rahim, H. L., Abidin, Z. Z. \& Rosly, H. E. (2016). Impact of entrepreneurship education effectiveness towards graduate employability. ASEAN Entrepreneurship Journal, 2 (1), 12-20.

Rainsbury, E., Hodges, D., Burchell, N. \& Lay, M. (2002). Ranking workplace competencies: Student and graduate perceptions. Asia-Pacific Journal of Cooperative Education, 3, 8-18.

Raposo, M. \& do Paço, A. (2011). Entrepreneurship education: Relationship between education and entrepreneurial activity. Psicothema, 23 (3), 453-457.

Rippa, P. \& Secundo, G. (2019). Digital academic entrepreneurship: The potential of digital technologies on academic entrepreneurship. Technological Forecasting and Social Change, 146, 900-911. https://doi.org/10.1016/j. techfore.2018.07.013

Salleh, K. M., Sulaiman, N. L., Mohamad, M. M. \& Sern, L. C. (2017). Assessing soft skills components in science and technology programs within Malaysian Technical Universities. Songklanakarin Journal of Science and Technology, 39 (3), 399-405. https://doi.org/10.14456/sjst-psu.2017.43 
Shakir, R. (2009). Soft skills at the Malaysian institutes of higher learning. Asia Pacific Education Review, 10, 309-315. https://doi.org/10.1007/s12564009-9038-8

Toding, M. \& Venesaar, U. (2018). Discovering and developing conceptual understanding of teaching and learning in entrepreneurship lecturers. Education and Training, 60 (7/8), 696-718. https://doi.org/10.1108/ET07-2017-0101

Yaghoubi Farani, A., Karimi, S. \& Motaghed, M. (2017). The role of entrepreneurial knowledge as a competence in shaping Iranian students' career intentions to start a new digital business. European Journal of Training and Development, 41 (1), 83-100. https://doi.org/10.1108/EJTD-07-2016-0054 
